\title{
Variance in Juvenile Accretionary Pyroclasts of the Attawapiskat Kimberlites: Implications for Eruption Dynamics and Interpretation of Volcanic Processes from Drill Core
}

\author{
Nathalie S. Lefebvre ${ }^{1}$, Alexandrina Fulop ${ }^{1,2}$, Stephan Kurszlaukis ${ }^{1}$ \\ ${ }^{1}$ De Beers Canada Inc., Toronto, Canada \\ ${ }^{2}$ North University, Baia Mare, Romania
}

\section{Introduction}

Juvenile accretionary pyroclasts (JAP; core-type, rimtype, and armored) were identified during detailed core logging of several kimberlite pipes within the Attawapiskat Kimberlite Field located in the James Bay Lowlands, Northern Ontario, Canada. The Jurassic-aged kimberlites were emplaced into water saturated karstic Ordovician to Devonian age strata of the Moose River Basin. The environment at the time of volcanic activity was likely a deltaic coastal plain.

Of the Attawapiskat Kimberlites studied, the X-ray kimberlite pipe contains some of the best preserved examples of JAP in kimberlites. Ten drill cores (Fig.1) from X-ray totaling $2126 \mathrm{~m}$ were logged in detail from which 193 polished slabs and thin sections were examined. The JAP were described and quantitatively measured from two representative polished slabs $(15 \mathrm{x}$ $6 \mathrm{~cm}$ area per slab) per geological unit following Schumacher and Schmincke (1991), and Webb (2006). Descriptions of JAP in kimberlite literature are rare. Most of the existing detailed studies and experiments are restricted to extra crater deposits of other volcanic systems and not from within a pipe where processes are very complex.

The purpose of this study is two-fold: 1 . To provide the first detailed descriptions of different types of JAP found in the Attawapiskat Kimberlite Field, as they can be diagnostic of a specific process and thus useful to identify a geological unit for economic purposes. 2 . To use the detailed JAP studies to help determine the volcanic processes that resulted in formation of the geological units from drill core, as well as any insights into kimberlite eruption column, vent and feeder conduit dynamics that these specific pyroclasts may provide.

\section{X-ray Pipe Geology and JAP Characteristics}

The X-ray pipe consists of four distinct geological units: XrVK1, XrVK2, XrVK3 and XrVK4 (Fig.1). For more detailed information on X-ray pipe geology refer to Fulop et al. (2008) in this volume. Three of the geological units, XrVK1, XrVK2, and XrVK3 contain JAP.

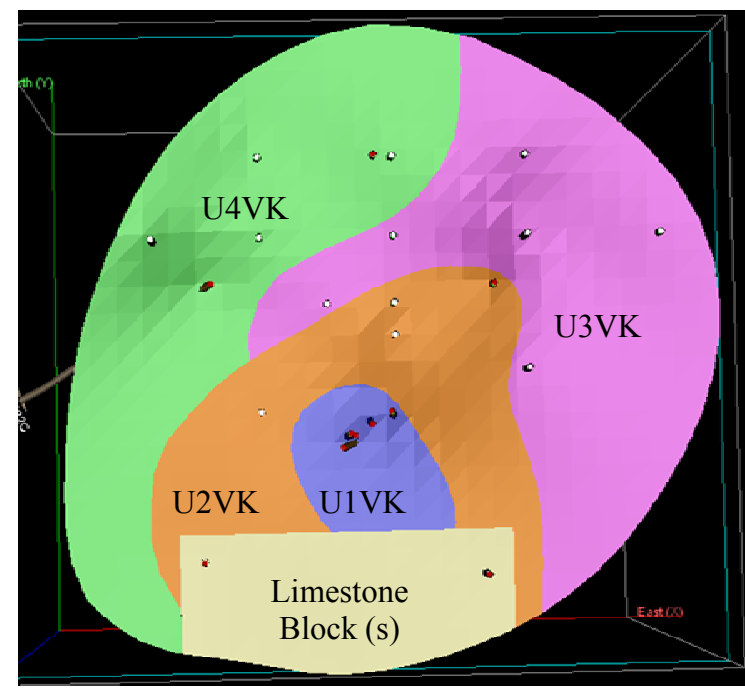

Figure 1: Plan view of the X-ray geological model. The length of the East $\mathrm{x}$-axis (red line) is $246 \mathrm{~m}$. Location of the ten drill cores that are part of this study are marked by red dots.

$\mathrm{XrVK} 1 \mathrm{XrVK} 1$ is the youngest volcaniclastic unit. It is generally matrix-supported, variably packed, and massive to crudely bedded with rare plastically deformed ash layers. The maximum unit thickness is $240 \mathrm{~m}$ in the southern central portion of the pipe. $\mathrm{XrVK} 1$ consists mainly of discrete olivine macrocrysts, phenocrysts and broken grains (modal abundance 35$45 \%$ ), country rock xenoliths (modal abundance 7$10 \%)$, and juvenile accretionary and coherent pyroclasts (modal abundance 5-10\%), set in a fine ash interclast matrix. This unit is interpreted as either a proximal, intra-vent pyroclastic or resedimented massflow deposit.

The JAP are typically randomly distributed throughout but can occur in localized concentrations. The relative JAP population comprises rim-type $(50 \%)$, core-type $(36 \%)$, and armored $(14 \%)$. Seven further subdivisions of JAP were identified: 1. rim-type with a coarse ash centre surrounded by a very thin fine ash rim (Fig.2), 2. rim-type with no core and with multiple-rims alternating from fine and coarse ash (Fig.2), 3. coretype of relatively unsorted coarse ash (Fig.3), 4. core- 
type with a relatively coarse center and slight diffuse grading to fine ash along the margin (Fig.3), 5. coretype of massive, fine ash (Fig.4), 6. armored with a solid center (xenolith or crystal) and a fine ash rim (Fig.4), and 7. armored with a solid center and multiple coarse and fine ash rims (Fig.5).
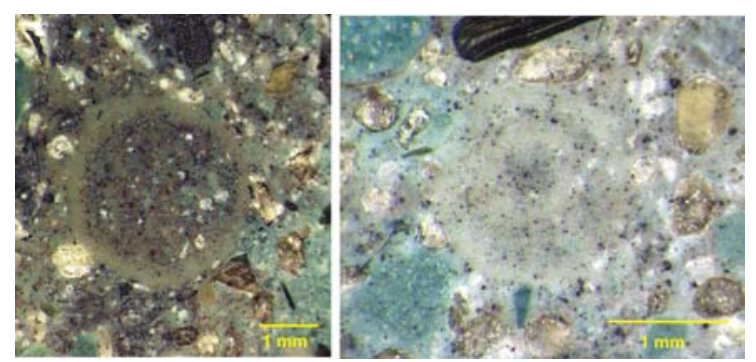

Figure 2: Slab photographs of rim-type JAP from unit XrVK1: coarse ash core with fine ash rim (left) and multiple rimmed coarser and fine ash (right).
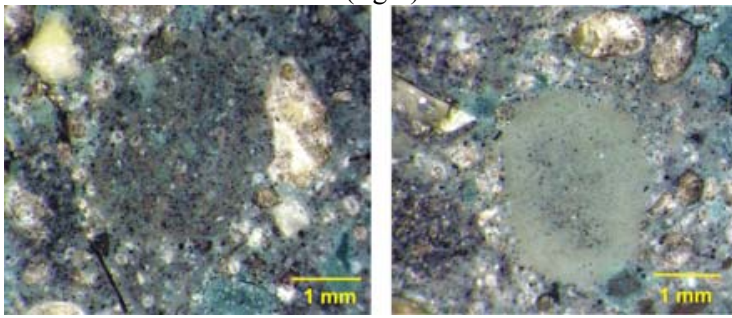

Figure 3: Slab photographs of core-type JAP from unit XrVK1: a relatively unsorted coarse ash (left) and a relatively coarse center with slight diffuse grading to fine ash along the margin (right).
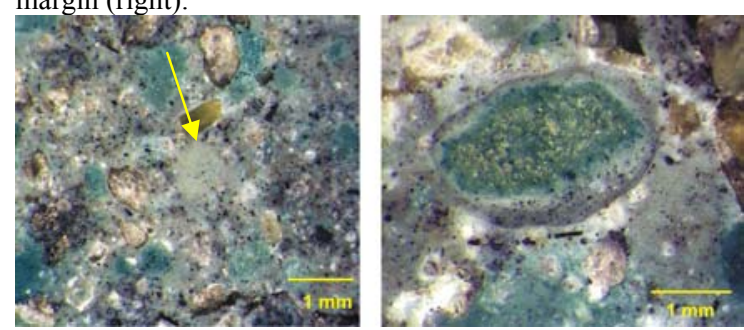

Figure 4: Slab photographs from XrVK1 of a core-type JAP of massive, fine ash (left) and an armored pyroclast with a blue limestone core and fine ash rim (right).

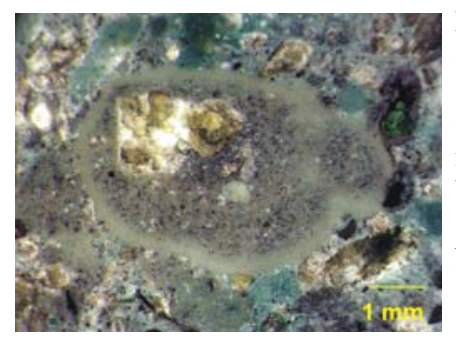

Figure 5: Slab photograph of a multiple rimmed armored JAP from XrVK1 consisting of an olivine macrocryst core followed by a coarse ash inner rim and a fine ash outer rim. Note the accretion of two smaller rim-type JAP on the right side.

The most frequent types in order of decreasing abundance are 1, 3, 5 and 6 , with relative abundances changing slightly with depth. Rim-type and armored JAP are dominantly subspherical in shape, as well as some core-type pyroclasts (aspect ratios < 1.5; Fig.6). The remainder of core-type pyroclasts have discoidal shapes (aspect ratios $>1.5$; Fig.6). The JAP are typically ash- to lapilli-sized, well rounded, and smoothly curved. Vesicles are typically absent but can be present up to $2 \%$. Armored and rim-type usually have asymmetrical incomplete rims and generally $\mathrm{C} / \mathrm{D}$ ratios $>0.7$ (Fig.7).

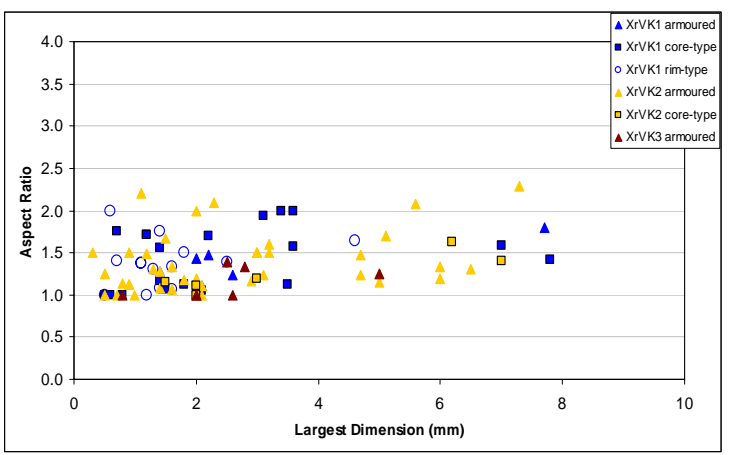

Figure 6: Plot of largest dimension against the aspect ratio (JAP longest/shortest dimension) of the different types of JAP types from units XrVK1, XrVK2, and XrVK3.

The mineralogy of the JAP, which is similar for all three units and to that of the host ash matrix, comprises some unidentifiable grey material, carbonate, likely spinel-perovskite, and magnetite as well as up to $5 \%$ unevenly distributed phenocrysts and broken grains of olivine $<0.5 \mathrm{~mm}$ in size. The relative abundance of these minerals varies depending on JAP grain size.

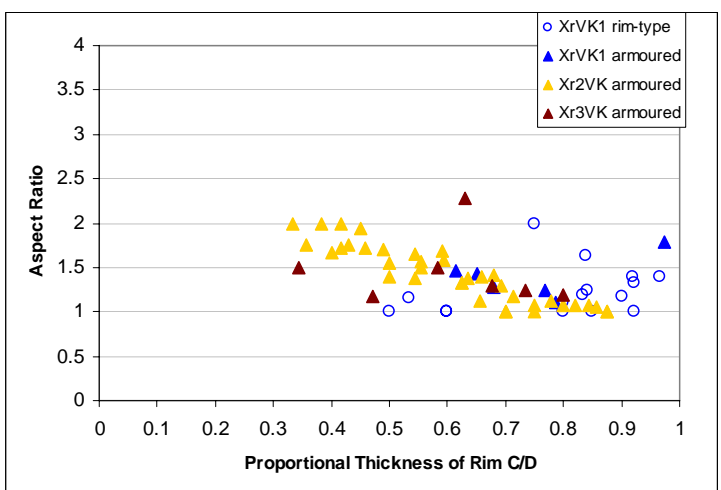

Figure 7: Plot of proportional thickness of $\operatorname{rim} \mathrm{C} / \mathrm{D}(\mathrm{C}=$ longest diameter of core and $\mathrm{D}=$ longest total diameter) against their aspect ratio (longest/shortest dimension) of the rim-type JAP from XrVK1 and the armored JAP from all three units.

$\mathrm{XrVK2}$ : $\mathrm{XrVK} 2$ is the second youngest unit which is distributed mainly in the southern part of the pipe where it ranges in thickness from 8 to $180 \mathrm{~m}$ (Fig.1). This volcaniclastic unit is matrix-supported, loosely packed and generally massive to crudely bedded with typical coarse tail grading and closer packing at its base. XrVK2 is interpreted as either a pyroclastic or resedimented mass-flow deposit. It typically comprises macrocrysts, phenocrysts and broken grains of discrete olivine (modal abundance 45-50\%), juvenile accretionary and coherent pyroclasts (modal abundance $1-2 \%$ ), and country rock xenoliths (modal abundance $10-15 \%$ ) set in a serpentine cement interclast matrix with localized ashy zones.

JAP are dispersed throughout the unit whereby $87 \%$ of the population are armored and $13 \%$ are core-type 
massive fine to coarser ash (Fig.8). Both types of JAP are generally ash- to lapilli-sized, well rounded, smoothly curved, non-vesicular and have subspherical to discoidal shapes with aspect ratios ranging from 1 to 2.3 (Fig.7). The armored JAP have variable C/D ratios (Fig.7) and typically asymmetrical complete to incomplete rims, 0.1 to $0.6 \mathrm{~mm}$ thick.
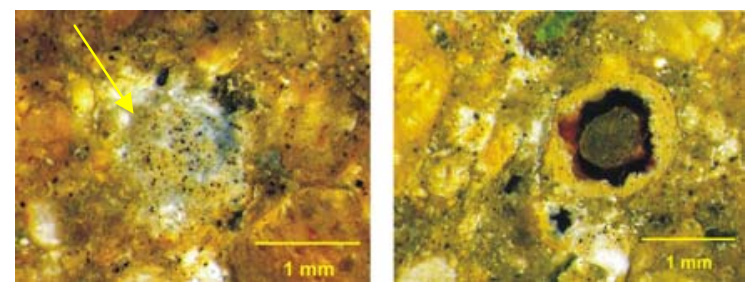

Figure 8: Slab photographs from unit XrVK2 of a core-type massive fine ash JAP (left) and an armored JAP (right) with an olivine macrocryst core and a fine ash rim.

$X r V K 3: \mathrm{Xr} 3 \mathrm{VK}$ is the oldest unit identified within the pipe. Based on its spatial distribution in drill core, it covers the bottom portion of the pipe and ranges from 7 to $180 \mathrm{~m}$ in thickness. $\mathrm{XrVK} 3$ is massive with rare localized crude bedding and shows an overall normal coarse tail grading of olivine and country rock xenoliths. The bottom of the unit is a coarser-grained matrix-supported, closely packed xenolith-rich zone that grades up into an upper finer-grained, matrixsupported, loosely packed xenolith-poorer zone. The $\mathrm{XrVK} 3$ is interpreted as a vent proximal mass-flow deposit. It generally comprises macrocrysts, broken grains and phenocrysts of discrete olivine (modal abundance 35-45\%), juvenile accretionary and coherent pyroclasts (modal abundance $\leq 1 \%$ ), and country rock xenoliths (modal abundance $7-35 \%$ ) set in an interclast matrix of carbonate and serpentine cement.

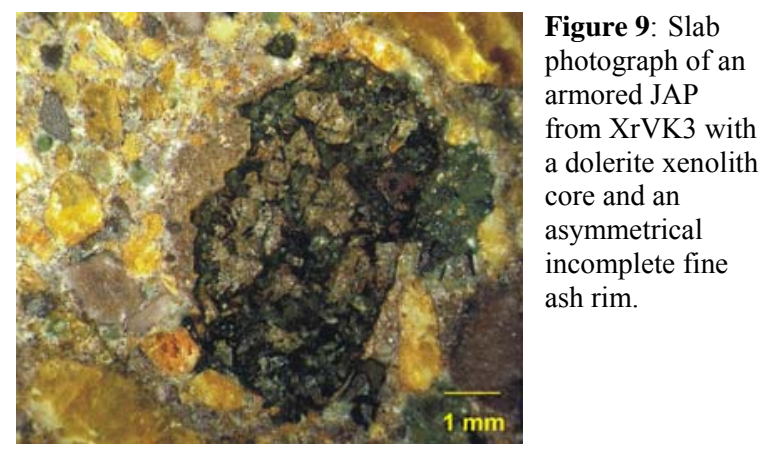

The JAP, which are dominantly armored (Fig.9), are more abundant in the lower coarser grained xenolithrich zone than in the upper finer-grained zone. The JAP are generally lapilli-sized, subspherical with aspect ratios $<1.5$ (Fig. 6), well sorted, non-vesicular, well rounded, and smoothly curved. The $\mathrm{C} / \mathrm{D}$ ratios range from 0.35 to 0.8 (fig.7), and the ash rims are asymmetrical incomplete and range from 0.1 to $1.2 \mathrm{~mm}$ thickness.

\section{Interpretation}

XrVK1, XrVK2 and XrVK3 all contain JAP signifying moist, turbulent ash clouds likely resulting from phreatomagmatic eruptions. The JAP look similar in morphology, and internal structure to those described from other volcanic systems. All three geological units are characterized by different and specific types and relative abundances of JAP.

By comparing the internal morphology, aspect ratios, and $\mathrm{C} / \mathrm{D}$ ratios of the X-ray JAP to those from known deposit types of other volcanic systems, the following may be inferred:

1. Within these units the JAP are of relatively low abundance and unevenly dispersed throughout. This suggests that some degree of movement and dilution of the original JAP layers has occurred.

2. XrVK1 contains both rim-type and core-type JAP, as well as all three units have armored JAP with a wide range of C/D ratios (Fig.7) indicating mixed populations. This variation could either represent a mix of JAP proximal to the erupting vent and distal JAP from neighbouring pipes, or more likely that it is a vent proximal phenomena whereby some areas within the vent had more moisture available than others.

3. The JAP from all three units were likely formed by pyroclastic surges based on the observation that core-type pyroclasts from XrVK1 and XrVK2 typically have aspect ratios $<1.5$ (Fig.6), the majority of rim-type pyroclasts from XrVK1 have aspect ratios $<1.5$ and $\mathrm{C} / \mathrm{D}$ ratios $>0.7$ (Fig.7), and the fact that armored JAP are often associated with surge deposits (ex. Schumacher and Schmincke, 1991; Scolamacchia et al, 2005).

\section{References}

Fulop, A., Lefebvre, N.S., Kurszlaukis, S., 2008. Emplacement Sequence in X-Ray Pipe, Attawapiskat Kimberlites, Ontario, Canada. $9^{\text {th }}$ International Kimberlite Conference Preceedings, Frankfurt, Germany.

Scolamacchia, T., Macias, J.L., Sheridan, M.F., Hughes, S.R., 2005. Morphology of ash aggregates from wet pyroclastic surges of the 1982 eruption of El Chichon Volcano, Mexico. Bulletin of Volcanology 68, 171-200.

Schumacher, R., Schmincke, H-U., 1991. Internal structure and occurrence of accretionary lapilli - a case study at Lacher See Volcano. Bulletin of Volcanology 53, 612-634.

Webb, K.J., 2006. Juvenile clasts in kimberlite: standardized comprehensive description towards unravelling emplacement mechanisms. In: B.H. Scott-Smith (Ed.), Kimberlite Emplacement Workshop, Saskatoon, Canada.

Contact: N.S. Lefebvre

nathalie.lefebvre@ca.debeersgroup.com 